\title{
Liniment Dosage Form
}

National Cancer Institute

\section{Source}

National Cancer Institute. Liniment Dosage Form. NCI Thesaurus. Code C42949.

A semi-solid with viscosity similar to that of a lotion, which is intended for topical use and must be rubbed into the site of administration to release the active and/or inert ing redient(s). 